\title{
TroyAcademy
}

International Journal of Social Sciences

\section{The Effect of Autotelic Personality on Work Engagement Level of Employees: Role of Personal Meaning}

\author{
Araştırma Makalesi/Research Article
}

Pelin KANTEN* Benan ARDA**

\begin{abstract}
This study aims to investigate the effects of autotelic personality on work engagement levels of employees and the mediating role of personal meaning. For the purpose of the research, the data which were collected from 162 employees who have been working in service and public industry by the survey method were analyzed by using partial least squares-structural equation modeling method. While conducting analysis, Smart PLS program was used by applying bootstrapping technique (5000 resample) to determine the significance levels of the proposed hypotheses and also Anderson and Gerbing (1988) two-step approach has been used. According to the research results, it is found out that the dimensions of autotelic personality labelled as curiosity-persistence and attention control have a positive and significant effect on work engagement. However, research results indicate that personal meaning has a positive and significant effect on work engagement. In addition, it is found out personal meaning has partially mediating role in the relationship between curiosity-persistence and work engagement dimensions. On the other hand, this study demonstrate that positive personality traits are crucial antecedents of the favorable workplace attitudes and behaviors.
\end{abstract}

Keywords: Autotelic personality, Work engagement, Personal Meaning

\section{Ototelik Kişiliğin İşe Adanma Davranışı Üzerindeki Etkisinde Kişisel Anlam Arayışının Rolü}

\section{ÖZET}

Araştırma kapsamında ototelik kişiliğin işgörenlerin işe adanma düzeyleri üzerindeki etkileri ve kişisel anlamın aracı rolünün incelenmesi hedeflenmektedir. Araştırmanın amacı doğrultusunda hizmet ve kamu sektörlerinde çalışmakta olan 162 işgörenden anket yöntemi ile elde edilen veriler kısmi en küçük kareler-yapısal eşitlik modelleme yöntemi kullanılarak analiz edilmiştir. Analiz aşamasında belirlenen hipotezlerin anlamlılık düzeylerini belirlemek için önyükleme tekniği (5000 yeniden örnekleme) uygulanarak Smart PLS programı kullanılmış ve Anderson ve Gerbing'in (1988) iki aşamalı yaklaşımından yararlanılmıştır. Araştırma sonuçlarına göre, merak-süreklilik ve dikkat kontrolü olarak belirlenen ototelik kişilik boyutlarının işe

* Prof. Dr., Canakkale Onsekiz Mart University, Faculty of Political Sciences, pelinkanten@ comu.edu.tr, ORCID: 0000-0002-6487-0203

** Doktora Öğrencisi, Canakkale Onsekiz Mart University, Faculty of Political Sciences, benanciplak@gmail.com, ORCID: 0000-0001-7530-5966 
adanmışlık üzerinde pozitif ve anlamlı bir etkiye sahip olduğu sonucuna ulaşılmıştır. Araştırma sonuçları, kişisel anlamın da işe adanmışlık üzerinde olumlu ve anlamlı bir etkiye sahip olduğunu göstermektedir. Ayrıca meraksürekllik ve işe adanmışlık boyutları arasındaki ilişkide kişisel anlamın kısmen aracılık rolüne sahip olduğu tespit edilmiştir. Ayrıca araştırma ile, olumlu kişilik özelliklerinin, olumlu işyeri tutum ve davranışlarının

önemli öncülleri olduğunu ifade etmek mümkündür.

Anahtar Kelimeler: Ototelik Kişilik, İşe Adanma, Kişisel Anlam

\section{INTRODUCTION}

Recent years, it is seen that social and behavioral sciences indicated that the positive potentials of human existence rather than focus on pathological aspects of human behaviors. This new movement called as "positive psychology" which aims to highlight positive characteristics of individuals such as hope, wisdom, creativity, future mindedness, courage, responsibility, perseverance and flow. Flow is one of the common investigated concept in the field of positive psychology refers to the high motivation and high level of enjoyment (Asakawa, 2004: 123-124). However, flow is defined as integrated feelings which shows full involvement of the individuals. In other words, it refers to the feeling completely pleasant, enjoyable and absorption on the tasks which lead to high performance on the organizational context (Busch et al., 2013: 234-235). Csikszentmihalyi and Csikszentmihalyi (1988) described the individuals' characteristics who experience flow as autotelic 'personality. Autotelic 'personality is characterized as the individual who sets their own goals and aims to reach, then has great fun in achieving them (Tan and Chou, 2010: 5). Besides, autotelic 'personality represents favorable and powerful features such as curiosity, need to achievement, proactivity, creativity and openness to new experience and desire to personal growth. Due to these characteristics, it is suggested that autotelic 'personality lead to positive consequences in both work and social life like greater happiness and performance, productivity, well-being, commitment, engagement and etc. (Biason, 2018: 11). On the other hand, it is asserted that the significant characteristic of autotelic personality which is labelled as flow facilitates personal meaning of individuals (Yarar, 2015: 7). Therefore, it can be inferred that based on the autotelic personality trait crucial role on positive attitudes in the workplace, its consequences should be explored. Accordingly, this study aims to examine one of the positive personality trait which is called as autotelic 'personality and its effect on work engagement and personal meaning. However, there is limited research in the existing literature yet examining the autotelic 'personality and both antecedents and its consequences. Thus, this study aims to determine the effect of autotelic 'personality on positive attitudes, so it attempts to add contribution to the literature. 


\section{THEORETICAL FRAMEWORK AND HYPOTHESES DEVELOPMENT}

As scope of the individual differences autotelic "personality considered one of the component which has a significant effect on human attitudes. Autotelic "personality characterized as someone who is able to enjoy even if he or she does not get external rewards and likely to experience flow in an organizational activity (Tan and Chou, 2010: 5-8). In other words, the activities of autotelic 'person regarded as self-contained activities which is not exhibited expectations of benefits but doing that activity itself considered as reward. Autotelic concept is derived from the two Greek words auto and telic, while auto refers to the self; telic represents goal. Therefore, autotelic 'personality defined as a person who has a persistent desire to learn and wish to attain success, adapt to changing conditions, like to create opportunities (Baumann, 2012: 166-167). Due to the positive characteristics of autotelic personality, it is suggested that these individuals have propensity to engage in a behavior such as solving problems, overcome obstacles and meeting challenging standards of excellence (Busch et al., 2013: 241). In literature researchers asserted that there are many benefits of having an autotelic personality such as greater happiness- creativity, productivity and well-being (Biason, 2018: 12). Asakawa (2004) found out that autotelic personality lead to increasing psychological well-being of individuals. Mikicin (2013) emphasized that autotelic personality is predictor of engagement. Tse et al. (2020) suggested that autotelic personality has a positive effect on well-being through flow experience and deep engagement.

Engagement characterized as an involvement, commitment, enthusiasm, absorption and full of energy. Merriam-Webster dictionary defined engagement as "emotional involvement or commitment" and as "the state of being at work voluntarily". Kahn is the first scholar who conceptualized engagement at work described it as the "attachment of the employees to their work roles and exhibit work performance physically, cognitively and emotionally (Schaufeli, 2012: 3). In other words, work engagement refers a positive state which consist of vigor, dedication, and absorption. Vigor refers to employees show high levels of energy and resilience in work. Dedication is representing high attachment employees with enthusiasm. The other component of absorption characterized as employees to show full concentration and forget oneself at work (Yongxing et al., 2017: 708). Kahn's (1990) engagement theory suggested that engagement is affected by three antecedents which are labelled as job characteristics, social environment and personal traits (Bailey et al., 2015: 14). For example, individuals who have positive traits perceive their work environment favorable and may have a high level of engagement. Work engagement based on both situational and individual factors (Kanten and Yeşiltaş, 2015: 1368). In the context of individual factors like personality such as low hardiness, typeA personality, lower self-esteem, high expectations and big five personality components as the 
predictors of work engagement (Brew and Machiha, 2019: 6). Accordingly, it can be assumed that one of the positive traits which is characterized as autotelic personality and its dimensions have significant effect on work engagement components, so following hypotheses are proposed:

$\mathrm{H}_{1}$ : Curiosity-persistence influences absorption levels of employees.

$\mathrm{H}_{2}$ : Curiosity- persistence influences dedication levels of employees.

$\mathrm{H}_{3}$ : Curiosity- persistence influences vigor levels of employees.

$\mathrm{H}_{4}$ : Low self-centered influences absorption levels of employees.

$\mathrm{H}_{5}$ : Low self-centered influences dedication levels of employees.

$\mathrm{H}_{6}$ : Low self-centered influences vigor levels of employees.

$\mathrm{H}_{7}$ : Attentional control influences absorption levels of employees.

$\mathrm{H}_{8}$ : Attentional control influences dedication levels of employees.

$\mathrm{H}_{9}$ : Attentional control influences vigor levels of employees.

Meaning in life is considered as the core component of human experience and represents a significant topic in clinical and health psychology. It is described as the nature of individual's existence and indicates the attainment of valuable goals and accompanying sense of fulfillment (Carreno et al., 2020: 2). In this context, personal meaning can be described as the factor which makes individual's life crucial, coherent and valuable. However, it is also referring to the main source of motivation which effects individuals and their environment (Markow and Klenke, 2005: 11). Baumeister (1991) suggested that there are four component of personal meaning which are called as purpose, value, efficacy and self-worth. Purpose refers to the individual's willingness to reach goals in their lives, values facilitates interpreting of individuals' what is right and good in their life. While efficacy indicates the individual's belief of to overcome challenges, self-worth shows that individual's go beyond the satisfaction of self-interests and reached personal accomplishment in their life. Considering that when individuals satisfied these needs it is expected that they have to feel personal meaning (Pöhlmann et al., 2006: 109). However, in literature it is seen that researchers focus on about what constitutes personal meaning and created Personal Meaning Profile-Brief which assess the major components of personal meaning such as relationships, achievement, self-acceptance, intimacy, selfacceptance, fair treatment and religion (Carreno et al., 2020: 2).

In recent years personal meaning has drawn great attention due to the it is related to the positive traits and psychological strengths of individuals (Steger et al., 2006: 81). Due to the link between 
individuals' personality traits and personal meaning, researchers focus on its relationships (DemirbaşÇelik and Korkut-Owen, 2018: 94). Therefore (Steger et al., 2008); (Schnell and Becker, 2006) found that extraversion and conscientiousness related to the personal meaning. Personal meaning is a significant component which deeply rooted in human nature. It leads to what individuals feel, think and who the person is including personal characteristics. For example, it is suggested that some personality traits such as creativity, intelligence and inquisitiveness related with self-acceptance indicate that the component of personal meaning (Daum and Wiebe, 2003: 13).

$\mathrm{H}_{10}$ : Curiosity-persistence influences personal meaning levels of employees.

$\mathrm{H}_{11}$ : Low self-centered influences personal meaning levels of employees.

$\mathrm{H}_{12:}$ Attentional control influences personal meaning levels of employees.

Personal meaning considered as an essential source of motivation which influence individuals' and their environment. It is suggested personal meaning facilitates individuals' personal growth and also lead to engagement (Markow and Klenke, 2005: 11). However, personal meaning examined as one of the significant component of psychological well-being which provide improvement in the quality of life and well-being (Carreno et al., 2020: 2). On the other side, theory of planned behavior asserted that personal meaning as the strong predictor of human behavior. For example, it is indicated that individuals who have high personal meaning attached to the engagement activities such as sport, learning and work (Lee, 2019: 30). Therefore, due to the importance of personal meaning on wellbeing, it is accepted that also as major component which accompanies pleasure and engagement (Demirbaş-Çelik, 2018: 198). Accordingly, it can be assumed that personal meaning which is the crucial motivation source has a significant effect on work engagement, thus following hypotheses are proposed:

$\mathrm{H}_{13}$ : Personal meaning influences absorption levels of employees.

$\mathrm{H}_{14}$ : Personal meaning influences dedication levels of employees.

$\mathrm{H}_{15}$ : Personal meaning influences vigor levels of employees.

$\mathrm{H}_{16}$ : Personal meaning has a mediator role on the relationship between curiosity- persistence and absorption.

$\mathrm{H}_{17}$ : Personal meaning has a mediator role on the relationship between curiosity- persistence and dedication.

$\mathrm{H}_{18}$ : Personal meaning has a mediator role on the relationship between curiosity- persistence and vigor. 
$\mathrm{H}_{19}$ : Personal meaning has a mediator role on the relationship between low self-centered and absorption.

$\mathrm{H}_{20}$ : Personal meaning has a mediator role on the relationship between low self-centered and dedication.

$\mathrm{H}_{21}$ : Personal meaning has a mediator role on the relationship between low self-centered and vigor.

$\mathrm{H}_{22}$ : Personal meaning has a mediator role on the relationship between attention control and absorption.

$\mathrm{H}_{23}$ : Personal meaning has a mediator role on the relationship between attention control and dedication.

$\mathrm{H}_{24}$ : Personal meaning has a mediator role on the relationship between attention control and vigor.

Figure 1. Research Model

Autotelic Personality Work Engagement

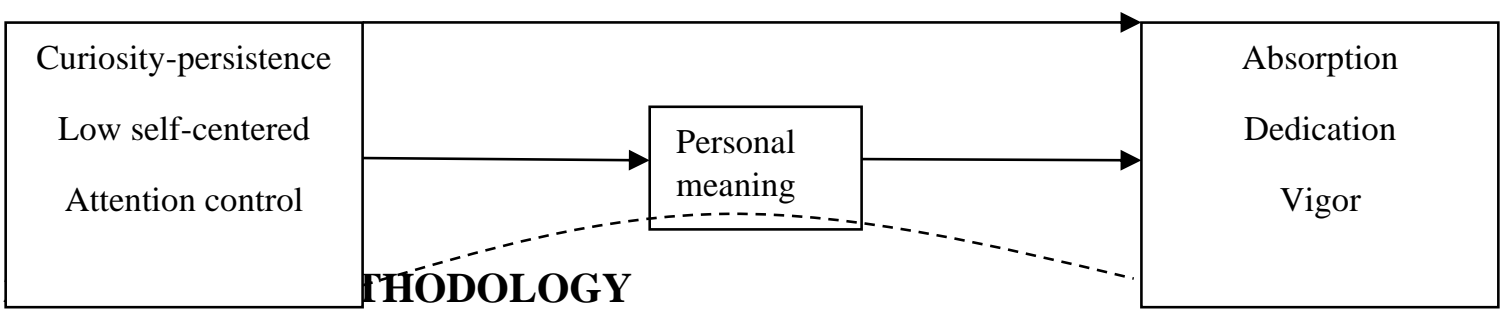

\subsection{Sample and Procedures}

The present sample of the research was composed of service and public sector employees who are located in six different provinces of Turkey. The participants constituted of 162 employees who have been working in service and public industry determined by a convenient sampling method. Out of 200 questionnaires that have been sent out by e-survey method and 170 data have been returned, representing a response rate of $82 \%$. After the elimination of the cases that have incomplete data and outliers, 162 questionnaires $(81 \%)$ have been accepted as valid and included in the evaluations. However, questionnaire survey method is used for data collection in this study. The questionnaire form contains three different measures related to research variables. Out of the 162 respondents, $52 \%$ were male and 48\% were female; 9\% were between 18 and 25 years, $49 \%$ were between 26 and 33 years, $23 \%$ were between 34 and 41 years, $19 \%$ older than 42 years. On the other hand majority of the participants (74\%) had a bachelor's and graduate degree. From the working area perspective, most of (73\%) the employees were working in a service industry and $23 \%$ of them working in a public institution. In addition, $40 \%$ of the participants had been working between 1 and 3 years, 23\% of them had been working between 4 and 7 years and 37\% of them had been working more than 8 years in the same sector. 


\subsection{Measures}

The measures used in the questionnaire forms have been adapted from the previous studies in the literature. As a result of the pilot study, some corrections were made in the questionnaire forms. A Likert-type metric, that is, expressions with five intervals has been used for answers to the statements of survey. Anchored such; "1- strongly disagree, 2- disagree, 3- agree or not agree, 4- agree, 5-strongly agree". Moreover, 5 demographic questions were included in the questionnaire form. Firstly, all scales were subjected to the exploratory factor analyses to check the dimensions, and then confirmatory factor analyses were applied to all scales.

- Autotelic Personality Scale: Autotelic personality scale was taken from Tse et al. (2020) study who have developed measurement of autotelic personality. Exploratory factor analyses using principle component analysis with varimax rotation was applied to the adapted scale to check the dimensions. As a result of the autotelic personality scale variables, 14 items were removed from the analysis due to the factor loading under 0.50 and three factor solutions (curiosity-persistence, low self-centered, attentional control) were obtained in accordance with the theoretical structure. Some examples of the items asked to the employees are as follows: "I am curious about the world"; "I find it hard to choose where my attention goes"; "I am afraid of making the wrong impression".

-Work Engagement Scale: Work engagement scale was taken from Kanten (2012) study. Exploratory factor analyses using principle component analysis with varimax rotation was applied to the adapted scale to check the dimensions. As a result of the work engagement scale variables, 2 items were removed from the analysis due to the factor loading under 0.50 and three factor solutions (dedication, vigor and absorption) were obtained in accordance with the theoretical structure. Some examples of the items asked to the employees are as follows: "To me, my job is challenging"; "I get carried away when I am working"; At my job, I am very resilient, mentally".

- Personal Meaning Scale: Personal meaning was measured with 8 items which was developed by Wong (1998). As a result of the exploratory factor analyses, 2 items were removed from the analysis due to the factor loading under 0.50 and one factor solution were obtained in accordance with the theoretical structure. Some examples of the items asked to the employees are as follows: "My life as a whole has meaning"; "I am able to spend most of my time in meaningful activities and pursuits".

\subsection{Data Analysis}

SPSS for Windows 22 and SmartPLS v3 were used to analyze the obtained data. SPSS 22 version used for the descriptive statistics and reliability analysis and assessing the demographic profile of the sample. Smart PLS v3 used for testing the hypotheses by employing partial least squares-structural equation modeling method. Therefore, partial least squares (PLS) based SEM was used in this study. 
PLS is considered as a well known method for estimating path coefficients in structural models and it is seen capable under the non-normality conditions and small samples (Ali et al., 2016: 91). While conducting analysis, Smart PLS program was used by applying bootstrapping technique (5000 resample) to determine the significance levels of the proposed hypotheses and also Anderson and Gerbing (1988) two-step approach has been used. According to this approach, first the measurement model needs to be tested by performing validity and reliability for each measure. After obtaining acceptable values, it can be proceeding with the structural model.

\section{RESEARCH FINDINGS}

\subsection{Measurement Model}

In scope of the measurement model, convergent validity and discriminant validity were tested. Within the convergent validity, factor loadings, composite reliability (CR), and average variance extracted values were computed. Table 1 shows that factor loadings, composite reliability values greater than the recommended value of 0.7 and also average variance extracted is exceeded the recommended value of 0.5 (Hair et al., 2006).

Table 1. Summary Table of Validity and Reliability

\begin{tabular}{|l|c|c|c|c|}
\hline \multicolumn{1}{|c|}{ Variables } & $\begin{array}{c}\text { Factor } \\
\text { Loadings }\end{array}$ & $\begin{array}{c}\text { Cronbach's } \\
\text { Alpha }\end{array}$ & $\begin{array}{c}\text { Average } \\
\text { Composite } \\
\text { Reliability }\end{array}$ & $\begin{array}{c}\text { Variance } \\
\text { Extracted } \\
\text { (AVE) }\end{array}$ \\
\hline Curiosity-persistence & $0.506-0.822$ & 0.839 & 0.878 & 0.513 \\
\hline Low self-centered & $0.624-0.889$ & 0.835 & 0.870 & 0.630 \\
\hline Attention control & $0.512-0.946$ & 0.557 & 0.713 & 0.509 \\
\hline Absorption & $0.411-0.864$ & 0.852 & 0.892 & 0.589 \\
\hline Dedication & $0.808-0.925$ & 0.927 & 0.945 & 0.777 \\
\hline Vigor & $0.677-0.928$ & 0.912 & 0.936 & 0.747 \\
\hline Personal meaning & $0.687-0.859$ & 0.887 & 0.913 & 0.638 \\
\hline
\end{tabular}

The next step as part of the measurement model was to evaluate the discriminant validity. Discriminant validity provided when the square root of the AVE (diagonal values) of each construct is larger than its corresponding correlation coefficients (Fornell \& Larcker, 1981). Table 2 shows that each indicator's loadings on its own construct are higher than all cross loadings with other constructs. Thus, it can be said that measurement model showed convergent validity and discriminant validity criteria were provided.

Table 2. Discriminant Validity

\begin{tabular}{|l|c|c|c|c|c|c|c|}
\hline & $\begin{array}{c}\text { Curiosity- } \\
\text { persistence }\end{array}$ & $\begin{array}{c}\text { Low self- } \\
\text { centered }\end{array}$ & $\begin{array}{c}\text { Attention } \\
\text { control }\end{array}$ & Absorption & Dedication & Vigor & $\begin{array}{c}\text { Personal } \\
\text { meaning }\end{array}$ \\
\hline $\begin{array}{l}\text { Curiosity- } \\
\text { persistence }\end{array}$ & 0.716 & & & & & & \\
\hline
\end{tabular}




\begin{tabular}{|l|c|c|c|c|c|c|c|}
\hline $\begin{array}{l}\text { Low self- } \\
\text { centered }\end{array}$ & 0.253 & $\mathbf{0 . 7 9 4}$ & & & & & \\
\hline $\begin{array}{l}\text { Attention } \\
\text { control }\end{array}$ & -0.036 & 0.387 & $\mathbf{0 . 7 1 3}$ & & & & \\
\hline Absorption & 0.644 & 0.238 & -0.063 & $\mathbf{0 . 7 6 7}$ & & & \\
\hline Dedication & 0.632 & 0.242 & -0.146 & 0.724 & $\mathbf{0 . 8 8 1}$ & & \\
\hline Vigor & 0.626 & 0.139 & -0.196 & 0.752 & 0.831 & $\mathbf{0 . 8 6 4}$ & \\
\hline $\begin{array}{l}\text { Personal } \\
\text { meaning }\end{array}$ & 0.547 & 0.162 & -0.001 & 0.542 & 0.654 & 0.588 & $\mathbf{0 . 7 9 9}$ \\
\hline
\end{tabular}

\subsection{Structural Model}

With using Smart PLS v3 and bootstrapping procedure by 5000 iterations structural model and hypotheses were tested. In this step, for the explanation power the standardized $\mathrm{R}^{2}$ and for assessing the model fit standardized root mean square residual (SRMR) were computed. In this model SRMR value was observed 0.080 , shows that model has an acceptable. Standardized $\mathrm{R}^{2}$ refers to the explanatory level of independent variable on dependent variable. Therefore, the independent variable dimensions (curiosity persistence, low self-centered and attention control) and the mediator variables (personal meaning) explain $47 \%$ of the employees' absorption levels. In addition, autotelic personality dimensions and personal meaning explain $57 \%$ of the employee's dedication levels and also autotelic personality dimensions and personal meaning explain $51 \%$ of the employee's vigor levels. Figure 2 shows the results of the structural model analysis. However, autotelic personality dimensions (curiosity persistence, low self-centered and attention control) explain $30 \%$ of the employees personal meaning levels.

Figure 2. Structural Model

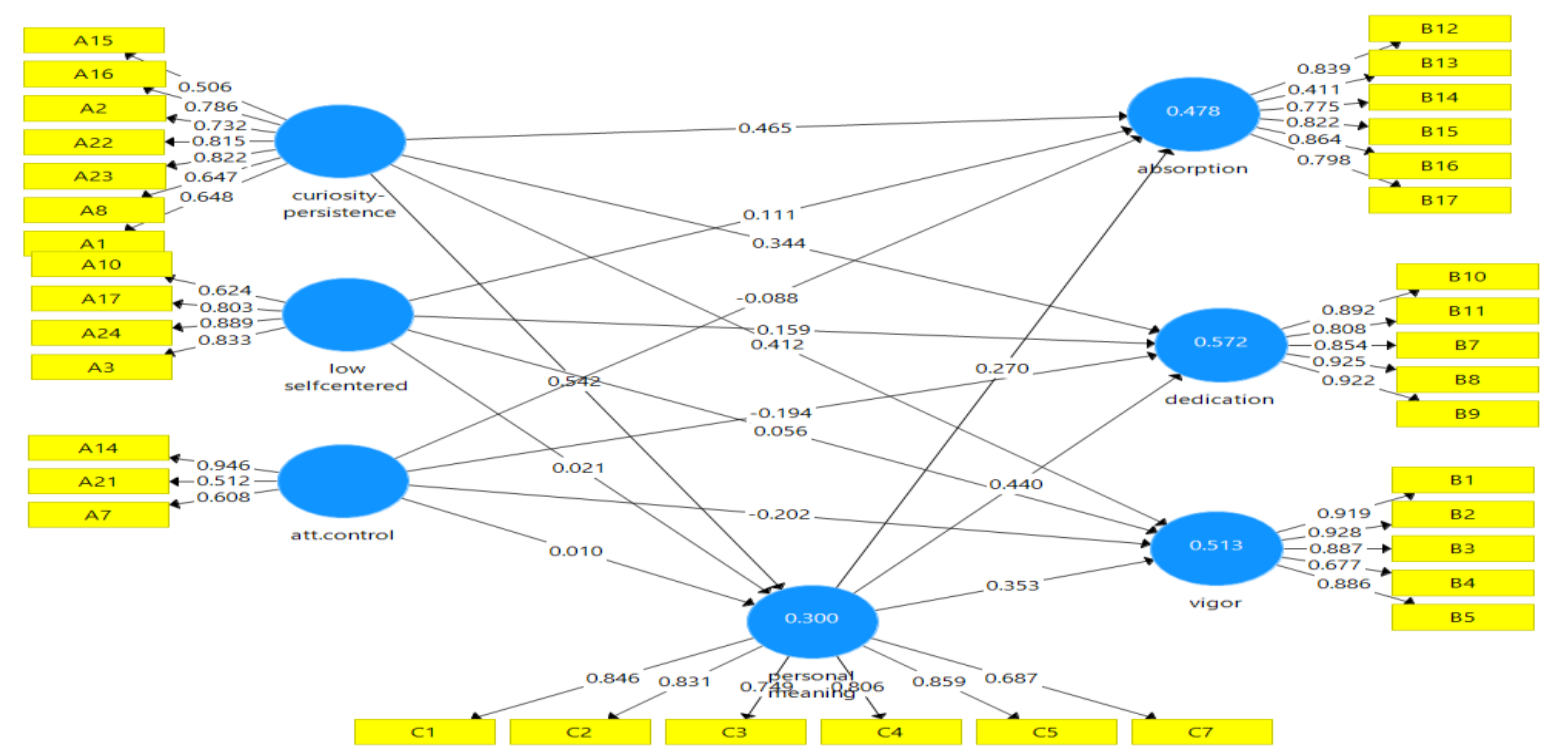

After giving structural model, the direct and indirect effects of structural model and hypotheses testing are presented in Table 3. 
Table 3. Direct and Indirect Effects of Structural Model and Path Coefficients

\begin{tabular}{|c|c|c|c|c|}
\hline Hypotheses & $\beta$ & $\begin{array}{c}\mathrm{T} \\
\text { values }\end{array}$ & P values & Results \\
\hline $\mathrm{H}_{1}$ : Curiosity-Persistence $\longrightarrow$ Absorption & 0.465 & 6.102 & 0.000 & Supported \\
\hline $\mathrm{H}_{2}:$ Curiosity-Persistence $\longrightarrow$ Dedication & 0.344 & 4.689 & 0.000 & Supported \\
\hline $\mathrm{H}_{3}:$ Curiosity-Persistence $\longrightarrow$ Vigor & 0.412 & 4.883 & 0.000 & Supported \\
\hline $\mathrm{H}_{4}$ : Low self-centered $\longrightarrow$ Absorption & 0.111 & 1.325 & 0.185 & $\begin{array}{l}\text { Not } \\
\text { supported }\end{array}$ \\
\hline $\mathrm{H}_{5}$ : Low self-centered $\longrightarrow$ Vigor & 0.056 & 0.627 & 0.531 & $\begin{array}{l}\text { Not } \\
\text { supported }\end{array}$ \\
\hline $\mathrm{H}_{6}:$ Low self-centered $\longrightarrow \quad$ Dedication & 0.159 & 1.786 & 0.074 & $\begin{array}{l}\text { Not } \\
\text { supported }\end{array}$ \\
\hline $\mathrm{H}_{7}:$ Attention control $\longrightarrow$ Absorption & -0.088 & 1.008 & 0.314 & $\begin{array}{l}\text { Not } \\
\text { supported }\end{array}$ \\
\hline $\mathrm{H}_{8}:$ Attention control $\longrightarrow \quad$ Dedication & -0.194 & 1.967 & 0.049 & Supported \\
\hline $\mathrm{H}_{9}:$ Attention control $\longrightarrow \quad$ Vigor & -0.202 & 1.990 & 0.047 & Supported \\
\hline $\begin{array}{l}\mathrm{H}_{10}: \text { Curiosity-Persistence } \longrightarrow \text { Personal } \\
\text { meaning }\end{array}$ & 0.542 & 7.457 & 0.000 & Supported \\
\hline $\mathrm{H}_{11}:$ Low self-centered $\longrightarrow$ Personal meaning & 0.021 & 0.231 & 0.817 & $\begin{array}{l}\text { Not } \\
\text { supported }\end{array}$ \\
\hline $\mathrm{H}_{12}:$ Attention control $\longrightarrow$ Personal meaning & 0.010 & 0.128 & 0.898 & $\begin{array}{l}\text { Not } \\
\text { supported }\end{array}$ \\
\hline $\mathrm{H}_{13}$ : Personal meaning $\longrightarrow$ Absorption & 0.270 & 3.550 & 0.000 & Supported \\
\hline $\mathrm{H}_{14}:$ Personal meaning $\longrightarrow$ & 0.440 & 6.765 & 0.000 & Supported \\
\hline $\mathrm{H}_{15}$ : Personal meaning $\longrightarrow \quad$ Vigor & 0.353 & 4.648 & 0.000 & Supported \\
\hline $\begin{array}{l}\mathrm{H}_{16}: \text { Curiosity-Persistence } \longrightarrow \text { Personal meaning } \\
\longrightarrow \text { Absorption }\end{array}$ & 0.146 & 2.960 & 0.003 & Supported \\
\hline $\begin{array}{ll}\mathrm{H}_{17}: \text { Curiosity-Persistence } \longrightarrow \text { Personal meaning } \\
\longrightarrow \text { Dedication }\end{array}$ & 0.238 & 4.674 & 0.000 & Supported \\
\hline $\begin{array}{l}\mathrm{H}_{18}: \text { Curiosity-Persistence } \longrightarrow \text { Personal meaning } \\
\longrightarrow \text { Vigor }\end{array}$ & 0.191 & 3.870 & 0.000 & Supported \\
\hline $\begin{array}{l}\mathrm{H}_{19:} \text { Low self-centered } \longrightarrow \text { Personal meaning } \\
\longrightarrow \text { Absorption }\end{array}$ & 0.006 & 0.225 & 0.822 & $\begin{array}{l}\text { Not } \\
\text { supported }\end{array}$ \\
\hline $\begin{array}{l}\mathrm{H}_{20:} \text { Low self-centered } \longrightarrow \text { Personal meaning } \\
\longrightarrow \text { Dedication }\end{array}$ & 0.009 & 0.236 & 0.814 & $\begin{array}{l}\text { Not } \\
\text { supported }\end{array}$ \\
\hline $\begin{array}{ll}\mathrm{H}_{21}: \text { Low self-centered } \longrightarrow \text { Personal meaning } \\
\longrightarrow \text { Vigor }\end{array}$ & 0.007 & 0.241 & 0.810 & $\begin{array}{l}\text { Not } \\
\text { supported }\end{array}$ \\
\hline $\begin{array}{l}\mathrm{H}_{22}: \text { Attention control } \longrightarrow \text { Personal meaning } \\
\longrightarrow \text { Absorption }\end{array}$ & 0.003 & 0.125 & 0.901 & $\begin{array}{l}\text { Not } \\
\text { supported }\end{array}$ \\
\hline $\begin{array}{ll}\mathrm{H}_{23}: \text { Attention control } \longrightarrow \text { Personal meaning } \\
\longrightarrow \text { Dedication }\end{array}$ & 0.005 & 0.129 & 0.898 & $\begin{array}{l}\text { Not } \\
\text { supported }\end{array}$ \\
\hline $\begin{array}{l}\mathrm{H}_{24}: \text { Low self-centered } \longrightarrow \text { Personal meaning } \\
\longrightarrow \text { Vigor }\end{array}$ & 0.007 & 0.241 & 0.810 & $\begin{array}{l}\text { Not } \\
\text { supported }\end{array}$ \\
\hline
\end{tabular}

According to table 3, it is possible to express that the path parameter and significance levels show that curiosity persistence have positive and significant effect on absorption ( $\beta=0.465$; $t$-value $=6.102$ ); dedication $(\beta=0.344$; $t$-value $=4.684)$ and vigor $(\beta=0.412$; $t$-value $=4.883)$ levels of employees. Thus, $\mathrm{H}_{1} \mathrm{H}_{2}$ and $\mathrm{H}_{3}$ hypotheses were supported. However, research results indicate that attention control have negative and significant effect on dedication $(\beta=-0.194$; $t$-value $=1.967)$ and vigor $(\beta=-0.202$; $t$ value $=1.990$ ) levels of employees, so $_{8}$ and $\mathrm{H}_{9}$ hypotheses were supported. Attention control has no 
significant effect on absorption level of employees so $\mathrm{H}_{7}$ was not supported. On the other hand, autotelic personality dimension which is labelled as low self-centered has no significant effect on work engagement dimension. Therefore, $\mathrm{H}_{4}, \mathrm{H}_{5}$ and $\mathrm{H}_{6}$ hypotheses were not supported. Autotelic personality just one dimension called as curiosity persistence has a positive and significant effect on ( $\beta=0.542$; $t$ value $=7.457$ ) personal meaning so $\mathrm{H}_{10}$ was supported. The other dimensions (attention control and low self-centered) have no significant effect, $\mathrm{H}_{11}$ and $\mathrm{H}_{12}$ were not supported. The mediator variable as personal meaning have positive and significant effect on $(\beta=0.270$; $\mathrm{t}$-value $=3.550)$ absorption; dedication $(\beta=0.440 ; t-v a l u e=6.765)$ and vigor $(\beta=0.353$; $t$-value $=4.648)$ levels of employees. Thus, $\mathrm{H}_{13}, \mathrm{H}_{14}$ and $\mathrm{H}_{15}$ hypotheses were supported. In this study, it is tested the mediating effect of personal meaning on the relationship between curiosity persistence and work engagement dimension (absorption, dedication and vigor).

As to examine the mediating effects, Preacher and Hayes (2008), a bootstrap procedure was used to test the indirect effects of curiosity persistence on absorption via personal meaning. It is calculated 97.5\% confidence intervals (CI) of parameter estimates using 5000 data samples extracted from the raw data samples $(n=162)$. For model 1 , the regression coefficients of the mediator effect of personal meaning in the relationships between curiosity persistence and absorption level of employees ( $\beta$ $=0.146 \mathrm{p}<0.001)$ and the bootstrap confidence interval $(0.066$ LLCI and 0.260 ULCI) is significant as the $97.5 \%$ CI does not include zero, so $\mathrm{H}_{16}$ hypothesis was supported. For model 2 the regression coefficients of the mediator effect of personal meaning in the relationships between curiosity persistence and dedication level of employees $(\beta=0.238 \mathrm{p}<0.001)$ and the bootstrap confidence interval (0.152 LLCI and 0.352 ULCI) is significant as the $97.5 \%$ CI does not include zero and $\mathrm{H}_{17}$ hypothesis was supported. For model 3 the regression coefficients of the mediator effect of personal meaning in the relationships between curiosity persistence and vigor level of employees $(\beta=0.191$ $\mathrm{p}<0.001)$ and the bootstrap confidence interval (0.109 LLCI and 0.310 ULCI) is significant as the 97.5\% CI does not include zero and $\mathrm{H}_{18}$ hypothesis was supported.

In the study, mediating hypotheses were examined in line with the ones proposed by Zhou et al. (2010). Therefore, in order to estimate the size of the indirect effects of mediators, VAF \% (Variance Accounted for) was calculated. For model 1, the VAF value is $50 \%$ which indicates partial mediation. According to this result, $23 \%$ of the total effect of curiosity persistence on absorption is explained by indirect effect of personal meaning. For model 2 the VAF value is $40 \%$ which indicates partial mediation. This results shows that $40 \%$ of the total effect of curiosity persistence on dedication is explained by indirect effect of personal meaning. For model 3 the VAF value is $32 \%$ which indicates partial mediation reflects that the total effect of curiosity persistence on vigor is explained by indirect 
effect of personal meaning. Therefore, the results showed that the partial mediation have all relationships.

\section{CONCLUSION AND IMPLICATIONS}

As scope of the positive psychology one of the favorable trait called as autotelic personality that refers to the positive sides of human such as curiosity, creativity, proactivity and etc. In literature, it is suggested that autotelic personality lead to positive consequences in both work and social life like well-being, happiness, life satisfaction, high performance, motivation, commitment and engagement. Due to the importance of autotelic personality in work life, it is seen that researchers focus on positive consequences and the other variables related to this trait. In other words, positive personality traits are seen crucial for the organization as decreasing adverse attitudes and behaviors. Therefore, it is needed to employ individuals who possess a positive trait as to gain organizational survival and facilitate engagement. Work engagement considered as an attachment of the employees to their work roles and exhibit job performance voluntarily. Work engagement also characterized as positive and favorable job outcomes in the organizational area. These attitudes exhibited based on individual's dispositional positive characteristics such as personality traits or psychological characteristics like emotion, mood or meaning. Accordingly, in scope of this study, some positive antecedents of work engagement were evaluated. From the positive psychology perspective both autotelic personality and personal meaning were examined as the precursors of work engagement and also it is questioned the mediator role of personal meaning.

As a result of the research findings, it has been found that autotelic personality dimension which is labelled as curiosity persistence has a positive and significant effect on employees work engagement levels. According to this result, it can be inferred that employees who have creativity and willingness to learning may prone to attached their work voluntarily. Therefore, it is expected that innovative and patient employees have more dedication and full of energy in the work process. Besides, the other dimension of autotelic personality such as attention control has a negative and significant effect on work engagement vigor and dedication dimensions. This result shows that self-conscious and distractibility characteristics lead employees have lower level of dedication and energy to their work roles. In addition, autotelic personality only dimension of curiosity persistence has a positive and significant effect on personal meaning level of employees. Accordingly, it is possible to express that employees who have high creativity and willingness to growth themselves may prone to feel their life valuable and precious. On the other hand, personal meaning has a positive and significant effect on work engagement all dimensions. These result reveals that employees who have positive feeling to their life and well-being, it is expected to attached their work role more high and possess full of energy. 
Moreover, in case of the employees feel that their work life valuable they have voluntarily embedded to the work roles. However, it was found that personal meaning has partially mediator role on the relationship between curiosity persistence and work engagement all dimension such as absorption, vigor and dedication. According to this result, it can be inferred that employees who have creativity and proactivity may prone to engaged their work roles more high in case of they considered that their life valuable. That is, autotelic personality trait leads to employees to attached their work life voluntarily and full of energy but if they believed that their life meaningful and valuable have a tendency to exhibit more positive attitudes.

Consequently, it can be inferred that work engagement which represent positive attitudes based on employees' dispositional characteristic and organizational conditions. In literature, there are some studies which examined personality traits, values and feelings as the antecedents of work engagement. However, there is no study which emphasizes autotelic personality, personal meaning and work engagement together in service and public organizations. Therefore, research results indicate that it is needed to employ individuals who have positive characteristics which lead to increase positive attitudes in the working area. In addition, it is supposed that in case of the employees consider their life valuable and have well-being may have attached their work roles voluntarily. In that direction, organizations need to maintain positive organizational climate by the humanistic policies and procedures which provides employees well-being. Besides, it is expected that human resource implementation and organizational conditions may facilitate attachment and commitment to the work roles of employees. For the future studies, it is recommended that the research model can be tested larger samples. On the other hand, along with autotelic personality, positive psychological capital dimension can be added to the research model or as a mediator variable some organizational variables such as organizational climate may be taken. 


\section{REFERENCES}

Ali, F., Ryu, K. and Hussain, K. (2016). "Influence of Experiences on Memories, Satisfaction and Behavioral Intentions: A Study of Creative Tourism", Journal of Travel \&Tourism Marketing, 33 (1), 85-100.

Anderson, J.C. and Gerbing D.W. (1988). "Structural Equation Modelling in Practice: A Review and Recommended Two-Step Approach", Psychological Bulletin, 3(3), 411-423.

Asakawa, K. (2004). "Flow Experience and Autotelic Personality in Japanese College Students: How Do They Experience Challenges in Daily Life?", Journal of Happiness Studies, 5, 123-154.

Bailey, C., Madden, A., Alfes, K., and Fletcher, L. (2015). "The meaning, antecedents and outcomes of employee engagement: A narrative evidence synthesis", Online first publication. Doi: 10.1111/ijmr.12077, 1-57.

Baumann, N. (2012). "Autotelic Personality”, S. Engeser (ed.), Inside Advances in Flow Research, Springer Science+Business Medi, 165-186.

Baumeister, R. F. (1991). Meanings of life. New York: Guilford.

Biason, J. (2018). Flow Families: Do Maternal and Paternal Parenting Styles Foster Autotelic Personality?, Degree of Bachelor of Psychological Science (Honours), Australian College of Applied Psychology, Sydney.

Brew, G. and Machiha, M. (2019). "Predictors of Work Engagement among University Teachers: The Role of Personality and Perceived Organizational Support", Linnaeus University Faculty of Health and life sciences, Department of Psychology. Master Thesis 5PS22E.

Busch, H., Hofer, J., Chasiotis, A. and Campos, D. (2013). "The Achievement Flow Motive as an Element of The Autotelic Personality: Predicting Educational Attainment in Three Cultures", Eur J Psychol Educ, 28, 239-254.

Carreno, D. F., Eisenbeck, N., Cangas, A. J., García-Montes, J. M., Del Vas, L. G. and Maria, A. T. (2020). "Spanish Adaptation of The Personal Meaning Profile-Brief: Meaning in Life, Psychological Well-Being, and Distress", International Journal of Clinical and Health Psychology, 20, 151-162.

Csikszentmihalyi, M. (1988). The Future of Flow. In Csikszentmihalyi, M., and Csikszentmihalyi, I. S. (Eds.), Optimal Experience: Psychological Studies of Flow in Consciousness, 364-383. New York.

Daum, T. L. and Wiebe, G. (2003). Locus of Control, Personal Meaning, And Self-Concept Before and After an Academic Critical Incident. (Unpublished Doctoral Dissertion). Trinity Western University.

Demirbaş-Çelik, N. and Korkut-Owen, F. (2018). "Personality and Meaning in Life: The Mediating Role of Wellness", Universal Journal of Psychology, 6(3), 94-103. 
Demirbaş-Çelik, N. (2018). "Mental Well-Being Predictivity of Personal Meaning Profile in Various Age Groups", Journal of Education and Training Studies, 6(10), 198206.

Fornell, C., and Larcker, D. F. (1981). "Evaluating Structural Equation Models With Unobservable Variables and Measurement Error". Journal of Marketing Research, 18(1), 39-50.

Hair, J. F., Black, W. C., Babin, B. J., Anderson, R. E., and Tatham, R. L. (2006). Multivariate Data Analysis (6th ed.), Upper Saddle River, NJ: Prentice-Hall.

Kahn, W. A. (1990). "Psychological Conditions of Personal Engagement and Disengagement at Work", Academy of Management Journal, 33(4), 592-724.

Kanten, P. (2012). İşgörenlerde İşe Adanmanın Ve Proaktif Davranışların Oluşumunda Örgütsel Güven İle Örgütsel Özdeşleşmenin Rolü. (Yayımlanmamış Doktora Tezi). Isparta Süleyman Demirel Üniversitesi.

Kanten, P. and Yeşiltaş, M. (2015). "The Effects of Positive and Negative Perfectionism on Work Engagement, Psychological Well-Being and Emotional Exhaustion", Procedia Economics and Finance 23, 1367-1375.

Lee, C. S. (2019). Finding Personal Meaning and Self-Efficacy as Moderators of Behavioral Action in Social Anxiety. (Unpublished Doctoral Dissertion). University of Massachusetts Boston.

Markow, F. and Klenke, K. (2005). "The Effects of Personal Meaning and Calling on Organizational Commitment: An Empirical Investigation of Spiritual Leadership", The International Journal of Organizational Analysis, 13(1), 8-27.

Mikicin, M. (2013). "Autotelic personality as a predictor of engagement in sports", Biomedical Human Kinetics, 5, 84-92.

Pöhlmann, K., Gruss, B. and Joraschky, P. (2006). "Structural Properties of Personal Meaning Systems: A New Approach to Measuring Meaning of Life", The Journal of Positive Psychology, 1(3), 109-117.

Preacher, K. J., and Hayes, A. F. (2008). "Asymptotic and Resampling Strategies For Assessing And Comparing Indirect Effects in Multiple Mediator Models", Behavior Research Methods, 40, 879-891.

Schaufeli, W.B. (2012). "Work Engagement. What Do We Know and Where Do We Go?", Romanian Journal of Applied Psychology, 14 (1), 3-10.

Schnell, T. and Becker, P. (2006). "Personality and Meaning in Life", Personality and Individual Differences, 41, 117-129.

Steger, M. F., Frazier, P., Oishi, S. and Kaler, M. (2006). "The Meaning in Life Questionnaire: Assessing the Presence of and Search for Meaning in Life", Journal of Counseling Psychology, 53(1), 80-93. 
Steger, M. F., Kashdan, T. B., Sullivan, B. A. and Lorentz, D. (2008). "Understanding the Search for Meaning in Life: Personality, Cognitive Style, and the Dynamic Between Seeking and Experiencing Meaning”, Journal of Personality, 76(2), 199228.

Tan, F. B. and Chou, J. P. C. (2010). "Dimensions of Autotelic Personality and Their Effects on Perceived Playfulness in The Context of Mobile Information and Entertainment Services", Australasian Journal of Information Systems, 17(1), 522.

Tse, D. C. K., Nakamura, J. and Csikszentmihalyi, M. (2020). 'Living Well By Flowing' Well: The Indirect Effect of Autotelic Personality on Well-Being Through Flow Experience", The Journal of Positive Psychology, 1-12.

Wong, P. T. P. (1998). Implicit theories of meaningful life and the development of the personal meaning profile. In P. T. P. Wong, \& P. S. Fry (Eds.), The human quest for meaning: A handbook of psychological research and clinical applications (pp. 111-140). Mahwah, NJ: Erlbaum.

Yarar, O. F. (2015). Autotelic Personality: Links With Flow Propensity, Personal Strengths, and Psychopathology. (Unpublished Doctoral Dissertion). The Middle East Technical University.

Yongxing, G., Hongfei, D., Baoguo, X. and Lei, M. (2017). "Work engagement and job performance: the moderating role of perceived organizational support", Anales de psicología, 33 (3), 708-713. 